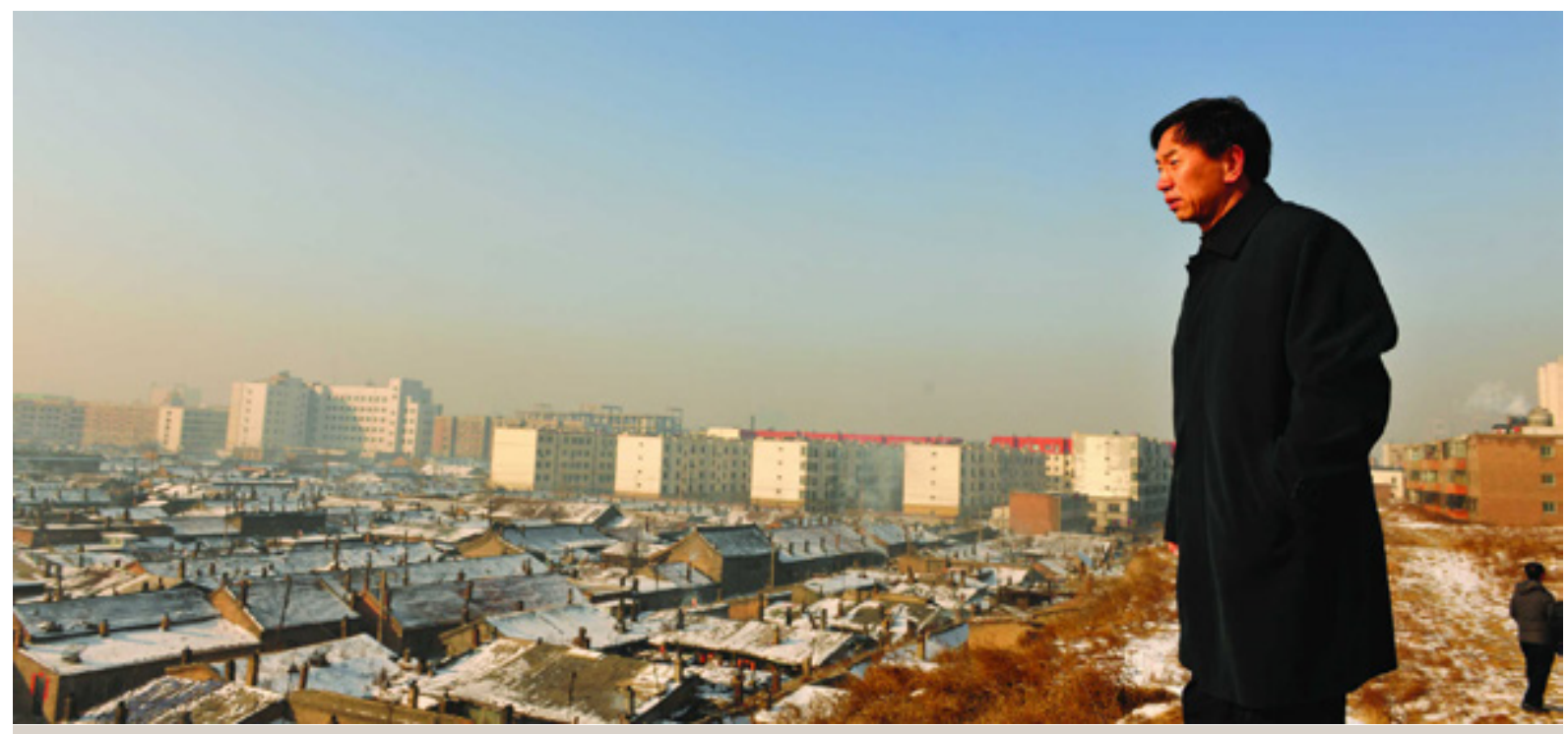

Still from The Chinese Mayor, directed by Zhou Hao, 2015

\section{Datong, Forever in Limbo}

\section{Jonathan Kinkel}

The 2015 documentary The Chinese Mayor by Zhou Hao documents the story of Datong, Shanxi province, as its leaders embark on an ambitious plan to transform the city into a tourist destination. Still, although the filmmakers devote sustained attention to the relocated residents and their demolished homes, the film is no exposé: it is mostly intended to educate an international audience on the internal workings of the Chinese policy-making process.
The history of the city of Datong, Shanxi province, plays a crucial role in The Chinese Mayor, a 2015 documentary by producer Zhao Qi and director Zhou Hao. The filmmakers explain at the outset that Datong was an imperial capital sixteen centuries ago, but at the turn of the twenty-first century it had become the most polluted city in China. Under his tenure as mayor of Datong from 2008 to 2013, Geng Yanbo had an ambitious plan: transform the city into a destination for visitors and capital by rebuilding the ancient city wall, thereby restoring the city's rich cultural and historical heritage. The only catch? As many as half a million people had to be relocated from their homes in order to complete the project.

The Chinese Mayor documents the city, its leaders, and its residents as the project unfolds, and although the filmmakers devote sustained attention to the residents relocated and the homes demolished to make way for the mayor's ambitions, the film is no exposé. According to Zhao, the film primarily aimed to educate an international audience on the internal workings of the Chinese policymaking process and to stimulate new ways of thinking about China. In accomplishing these goals, the filmmakers embed themes 
of tradition, grievance, and desperation that colour contemporary China's complex patterns of state-society relations. This approach provides rare glimpses into contemporary China's political system-a fact to which their 2015 Sundance Special Jury Prize for Unparalleled Access attestsas well as into China's distinct political-legal tradition. The filmmakers also strive to shape their rare footage into a coherent narrative with Mayor Geng at the center and the residents of Datong, who are ultimately left in limbo by larger political machinations, in supporting roles.

\section{Concession Via Confrontation}

Unsurprisingly, the mayor's grand plan to rebuild cultural Datong's old city wall encounters fierce resistance from several residents faced with the demolition of their homes. Recounted using extensive footage of the mayor's daily life and interactions with displaced citizens, the filmmakers tell a story of demolition and displacement familiar in many parts of the world, but which takes on a different hue in the context of China's unique tradition of ruler-subject relations. Datong's culturally themed land redevelopment is the mayor's brainchild, and he supervises or intervenes when necessary in the distribution of new apartments built to replace the demolished ones. Assigning a new flat to this or that citizen becomes the mayor's preferred method of gaining individual compliance with the forced relocations.

The narrative hinges on the development of a series of characters who express direct grievances to the mayor in the street or at demolition sites. In tears, one woman confronts the mayor while falling repeatedly and explains that due to her medical problems, she needs an apartment near her daughter's workplace. The mayor and his staff instruct her to wait ten days for a new apartment

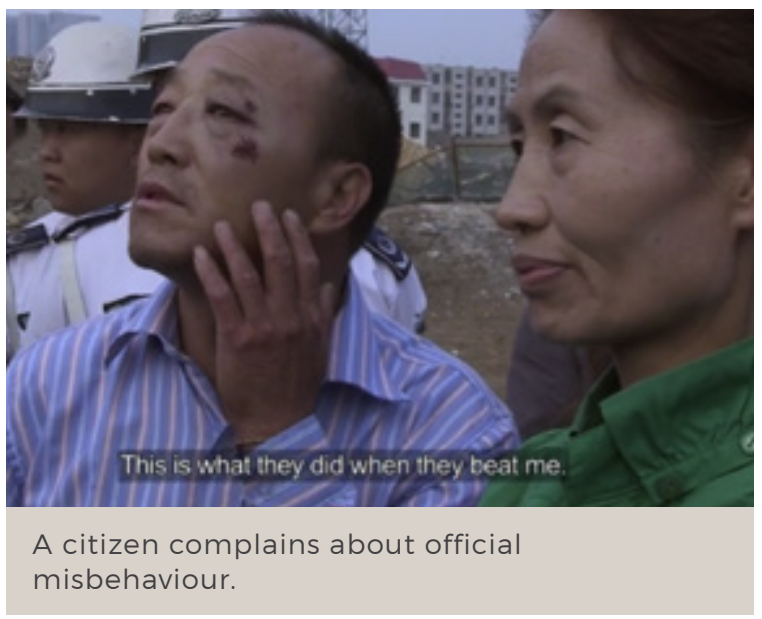

and assure her that they will address her concerns, on the condition that her medical situation can be confirmed. Another resident displaying facial injuries finds the mayor on the street and claims to have endured a beating from a deputy leader during the premature demolition of his home. After some squabbling, a member of the mayor's staff promises the man an apartment in what sounds like an idyllic community, 'Willow Garden'. An elderly resident, identified as 'Hua', confronts the mayor in separate scenes outside the mayoral residence (which, according to subtitles, is located in a military compound 'for safety reasons'). Instead of walking past her, the mayor listens to Hua's requests for compensation for her destroyed house and her arguments that she cannot climb the stairs to the sixth-floor apartment provided by the government. Mayor Geng tells her that she is asking for too much, but once he is in his car with his staff, he discusses whether he can get her an apartment on a lower floor.

Direct, impromptu interaction between citizens and government is not unique to Datong's demolition, but is rooted in a tradition of grievance and dialogue that has in some form mediated the relationship between ruler and subject in China for millennia. In the influential historical narrative Zuo's Commentary (Zuozhuan), which dates back to the late fourth century $\mathrm{BC}$, a politician 
reasons that it is better to learn from citizens' grievances than to silence them: 'I have heard of reducing grievances by means of loyalty and kindness; I have not heard of preventing grievances by exercising power... doing so would be like trying to prevent a river from overflowing with a dike... so I listen to criticism as a remedy.'

The influence of this tradition was also explicitly recognised at the beginning of the Communist era, when 'the right to make written or oral complaints' (shumian konggao huozhe koutou konggao de quanli) to organs of the state was enshrined in Article 97 of the original 1954 PRC Constitution. Though far from justiciable, the right to confront the state in this manner embodies the uniqueness of the Chinese political-legal system-it is among the few sections of the original Constitution of the People's Republic of China that was not lifted directly from the 1936 Soviet version.

\section{Desperation in the Narrative}

The tradition of citizens direct confrontation of government officials also survives in today's China in part because official channels for legal grievances are either inaccessible or easily subject to elite manipulation. A prominent supporting character in the film is identified as Hui, who is distinguished by her extensive legal knowledge and litigious outlook (in one scene, she recites State Council decrees for the camera from memory). Hui questions whether the demolition of her family's home exposes broader contradictions in Chinese society: 'Should I tell [my son] to trust the law and the government, and stand up for his rights? Or should I just tell him to give up?' When she confronts the mayor directly, Hui challenges his claim that her house was constructed illegally: 'That's a problem caused by the government. How come the government wasn't supervising before but blames the fault on us now?' The mayor replies feebly: 'Who never made a mistake?' Shortly thereafter, with Hui's appeals to China's Supreme People's Court finally denied, the camera surveys the demolished ruins of her house.

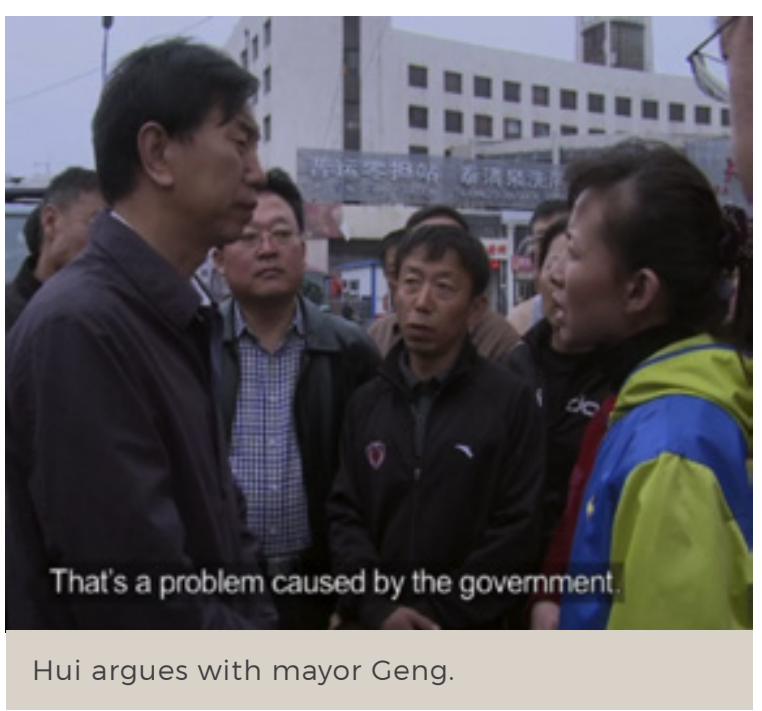

Scenes like these, in which citizens with seemingly legitimate claims cannot save their homes, build an aura of desperation that is carried forward as several characters in the film threaten suicide or indirectly reference death. One unidentified character resists the demolition of her brother's house and describes her brother and their family's forced relocation by saying: 'He ripped his belly open with a knife... I'll kill myself too... Let the corrupt rich guys live. We're not living!' The desperation of the mayor's own family also renders palpable the anxieties of people affected by the mayor's grand plans. For instance, Mayor Geng's wife confronts him at meetings and phones him repeatedly to bemoan their diminished family life: 'Have you [the mayor] had enough of living? Look at you.' In response, the mayor's calm, even affable demeanor comes off as ominous given the desperation of those surrounding him. When Mayor Geng tries to reassure his wife that he is not overworked, she replies: 'Are you trying to kill me?' 


\section{An Unfamiliar Resolution}

As the mayor's promises of new housing add up, and with desperation rising, an unanswered question looms in the background: what will happen if these pledges of new, alternative housing go unfulfilled? Near the end of the film, the central government 'rotates' (ganbu jiaoliu) Mayor Geng to a new post as Mayor of Taiyuan, before the completion of Datong's massive relocation and construction project. For the Western audiences targeted by the film's producers, rotation of mayors is most likely an unfamiliar concept. In China, however, the rotation of mayors and other local officials to several-year stints in different localities has long been a hallmark of China's Communist_nomenklatura system, a feature designed to prevent government officials from establishing parochial fiefdoms borne from close ties with local elites.

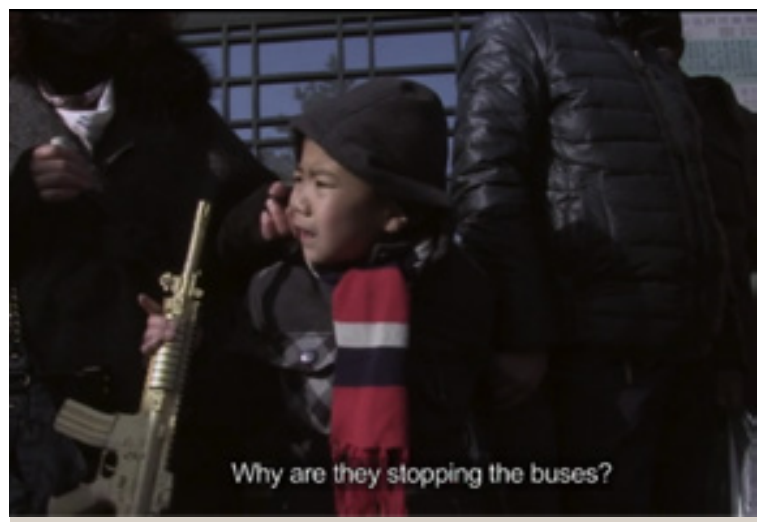

A young boy inquires about the protests that followed the mayor's abrupt departure from Datong.

To convey the import of the mayor's abrupt departure, the film employs a conversation between a young boy holding a golden toy machine gun and a woman (presumably the boy's mother). Amid large street demonstrations blocking traffic in protest at the mayor's transfer, the boy asks: 'Why are they stopping the buses?' She replies: 'They're asking for housing. No one will give them housing after Mayor Geng leaves. So, they're unhappy.' This explanation injects ambiguity into the film's resolution, as it is more cynical than the protesters' seemingly sincere chants of 'Come back, Mayor Geng!'

In these final scenes, where it is unclear whether Datong is furious over broken housing promises or distraught to lose a respected leader, the residents of Datong emerge as more sympathetic than the title character. Intriguingly, this tension is perhaps reflected in the alternative titles of the film-in some places the title is simply Datong instead of The Chinese Mayor. In contrast with the purgatory into which large, publicly financed reconstruction projects throw the relocated residents of cities like Datong-not to mention the three billion USD debt the mayor leaves behind-the rotation does not portend major consequences for Geng. In fact, the mayor ultimately plans to complete his political legacy in an even larger city, Shanxi's provincial capital Taiyuan, with a chance to dislocate even more residents: 'I wish I could have completed all my plans in Datong. But since I've been transferred, I'll create a "Cultural Taiyuan".' In the end, while the filmmakers' primary narrative intention might have been to capture the struggles faced by an idealistic mayor, they ultimately found greater success telling an historically infused story of affected residents, compelled to make sense of the debt-fuelled and politically engineered limbo thrust upon them.

\section{Jonathan Kinkel}

Jonathan J. Kinkel is Assistant Director of the Center for Asian Research at Arizona State University. He received a $\mathrm{PhD}$ in Government from UT-Austin in 2015, and his research focusses on the development of the Chinese legal system since the Cultural Revolution. 